
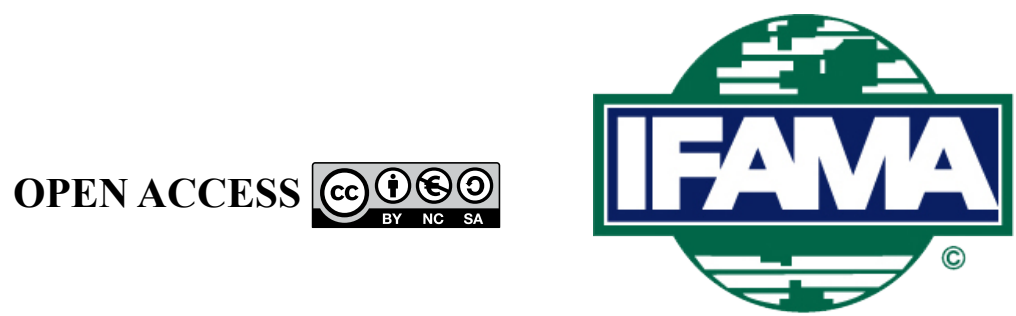

International Food and Agribusiness Management Review

Volume 25, Issue 3, 2022; DOI: 10.22434/IFAMR2020.0170

Received: 29 September 2020 / Accepted: 14 November 2021

\title{
Typology and performance of inter-organizational relationships among Ghanaian farmers
}

\section{RESEARCH ARTICLE}

\author{
Abigail Ampomah Adaku ${ }^{\circledR a}$ and Vincent Amanor-Boadu ${ }^{\mathrm{b}}$ \\ ${ }^{a}$ Lecturer, Department of Agricultural Economics and Agribusiness, \\ University of Ghana, P.O. Box LG 68, Legon-Accra, Ghana \\ ${ }^{b}$ Professor, Department of Agricultural Economics, Kansas State University, \\ 342 Waters Hall, 1643 Old Clafin Pl, Manhattan, KS 66506, USA
}

\begin{abstract}
This study explored inter-organizational relationships (IOR) between farmers and agri-food processors in Ghana and their relative effect on participating farmers' performance. The IOR were organized into three broad types: governance (formal/informal); orientation (price/quality/quantity); and structure (direct-to-buyer/ farmer-based organization (FBO)/agent). The study showed that about $44 \%$ of farmers participated in IOR, and $72 \%$ of them use direct-to-buyer relationships compared to $25 \%$ and $5 \%$ who use FBO and agent. The total exceeds $100 \%$ because some farmers used multiple IOR structures. Likewise, more than half of farmers involved in IOR use multiple orientations, with $29 \%, 81 \%$ and $54 \%$ of them using orientations involving quantity, quality, and price specifications, respectively. Formal governance IOR accounted for $31 \%$ of IOR by governance. On performance, the average farm income of farmers involved in IOR was GHS 3,947, which was 3.1 times higher than non-IOR farmers, and those with formal arrangements had 6.4 times higher average farm income than farmers in informal relationships. IOR with formal governance and quality-price orientation presented positive and statistically significant effects on marginal benefits while producer demographic and socio-economic characteristics did not. These results provide instruction for policymakers and practitioners in helping inform farmers' participation in IOR that produce superior outcomes.
\end{abstract}

Keywords: inter-organizational relationships, marginal benefit, farmer-based organization, governance JEL code: Q1

\footnotetext{
(1)Corresponding author: aaadaku@ug.edu.gh
} 


\section{Introduction}

Ronald Coase's Nobel-winning paper on the nature of the firm argued that economic agents will use alternative structures for exchanges if they present lower transaction costs than the market (Coase, 1937). Therefore, exmarket exchanges, such as those performed in strategic alliances, joint ventures, franchises, and outsourcing, aim to reduce the transaction costs that would otherwise be incurred in market exchanges (Choe, 2008). There is, therefore, an inherent expectation that participants in inter-organizational relationships (IOR) would have better performance than spot markets (Argyres and Zenger, 2012; Gomes-Casseres, 2003; Rao and Qaim, 2011). These potential benefits are motivating farmers, development practitioners, and government agencies to encourage the IOR formation (MoFA, 2017; Salifu et al., 2012). If the net benefits from participation in IOR are as suggested in the literature, then economic agents, acting in their self-interest, should need no more encouragement than the IOR gain to participate. Yet, participation is not universal, suggesting the possibility that not all potential participants may benefit from these relationships. Additionally, the existence of different types of IOR suggests that their benefits may differ by certain participant and/or transaction characteristics.

Excluding spot market transactions, Ghanaian farmers are known to use different types of relationships with their buyers (Abdul-Rahaman and Abdulai, 2019; Poku et al., 2018; Salifu et al., 2012). However, there is little information about the prevalence of these differences and virtually no information on their relative value to participating farmers. Furthermore, the potential role of the characteristics of farmers or products has not been studied, creating a gap in information needed by both policymakers and practitioners seeking to improve farmers' performance using IOR. The study seeks to address these gaps in the literature by (i) classifying and estimating the prevalence of the types of IOR used by Ghanaian farmers, and (ii) estimating the effect of relationship type and participant characteristic on the marginal benefit associated with the relationship. This should provide clear and empirical guidance for practitioners and policymakers to encourage IOR that fit the potential participant and product characteristics. Although the study is situated in Ghana, its results could apply to other sub-Saharan African countries when the products and channels available to farmers as well as the characteristics of farmers in those other countries are not dissimilar to the Ghana experience.

\section{Theoretical framework and literature review}

African agricultural production is often conceived of as a dual objective activity in which farmers maximize their household food security and their marketed surplus (Barrett, 2008; Yameogo et al., 2018). This paper departs from this assumption, arguing that farmers participating in IOR commit the part of their production associated with those relationships solely for commerce. This allows for the specification of a profit maximization objective function for these farmers. In this sense, farm households involved in IOR, like non-farm households involved with other businesses, address their consumption needs with returns from the business. This framing is necessary since entering inter-organizational relationships demands certain commitments and/or obligations to the relationship from its participants that non-participants do not have to make. These commitments and/or obligations may affect the production decisions and choices, including technologies, that these participants make (Amanor-Boadu et al., 2009). The farmer's objective when selling products, therefore, is to maximize profits.

Traditionally, farm products are sold in spots markets where transactions are based on the situation of demand and supply at the time of sale. There is intense competition to sell and agents pursue individual interests which could even be adversarial. Spot markets are characterized by price and sale uncertainties as well as information impactedness. This tends to make market exchanges vulnerable to opportunism (Williamson, 1973). Opportunistic behaviours as well as the actions that are taken to prevent them raise the cost of exchanges in the market. These costs are referred to as the transactions costs (Williamson, 1973, 1985). Transactions costs are therefore recognized as a reason for farmers to find alternative structures for exchanges (Adaku and Amanor-Boadu, 2021; Frank and Henderson, 1992; Henchion and McIntyre, 2010; Hobbs, 1997). IOR is an alternative structure to spot market exchanges and has the potential to reduce some of the cost of transactions in the market (Dubbert, 2019; Henchion and McIntyre, 2010; Miyata et al., 2009). 
It is generally accepted that IOR increases total costs because of additional obligations that may be demanded but those are more than compensated for by higher total revenues, leading to the general expectation of higher IOR benefits (Argyres and Zenger, 2012). Assuming this is true in this case, then the marginal benefit $(M B)$ from participation may be conceived of as being a function of the type of IOR given the participant and product characteristics. Participating farmers may be characterized by the type of crop enterprises in the relationship (X) (Hofstede et al., 2010) as well as their socio-economic characteristics $(W)$, such as education and age (Saxton, 1997), given the types of relationships $(Z)$ (Oliver, 1990). That is:

$$
M B=f(X, W, Z)
$$

Because production cost differences between IOR and spot market are assumed compensated, $M B$ may be determined empirically from the price received with participation and the spot market price. Suppose farmers participating in an IOR get a price premium, $x$, over and above the spot market price, $P$, then $M B$ may be derived from the following:

$$
\begin{aligned}
& R_{r}=Q(P+x), \text { and } \\
& R_{s}=Q P \\
& M B=\left(R_{r}-R_{s}\right) / R_{S}=[(Q P)+(Q P x)-(Q P)] /(Q P) \\
& M B=(Q x / Q P)=x / P
\end{aligned}
$$

where $R_{r}$ and $R_{s}$ are the total revenues emanating from IOR participation and the spot market, respectively, and the other variables are as defined. $M B$ is, thus, equal to the ratio of the price premium (the difference between the price received with participation and the spot market price) to the spot market price. Estimating $M B$ empirically has been challenging because of price differences across crops, time and participants (Provan and Sydow, 2009), contributing to the inability of empirical IOR research in the agri-food sector keeping pace with theoretical contributions (Galizzi and Venturini, 1999; Kataike and Gellynck, 2018; Oya, 2012). To overcome these challenges, the price premium was obtained by asking farmers the following question: 'Suppose the market price is GHS 1.00, how many more pesewas [100 pesewas = GHS 1.00] do you typically receive under your most profitable buyer relationship for each of your crops?'.

While this approach presents a potential risk of estimation error (Castrogiovanni, 1991), it presents methodologically lower risks than the commonly used measures of IOR performance: farm and/or household income, marketed output, and/or average price (Abdul-Rahaman and Abdulai, 2019; Alemu et al., 2016; Camanzi et al., 2018; Hobbs, 1995).

Three broad types of inter-organizational relationships are identified in the literature: Governance; Structure; and Orientation. Governance dichotomizes IOR into formal and informal relationships. Formal relationships typically involve written documents detailing participants' responsibilities and commitments to the relationship, while informal relationships generally involve verbal agreements, where participants' words are accepted as their bond (Abdul-Rahaman and Abdulai, 2019; Poku et al., 2018). Structure focuses on the channels used for constructing the relationship. Three types of structure were identified in the literature: direct-to-buyer; Farmer-based organization (FBO); and Agent or broker. Agents or brokers are independent of participating entities and take no title to exchanged products but may act on behalf of one of the parties to the relationship (Nigh, 1997; Simpson and Rapone, 2000). Direct-to-buyer involves farmers or suppliers dealing directly with their buyers (Kitamura et al., 2014).

Orientation organizes relationships based on their commitment factors (Krathu et al., 2015). Three specifications are identified in the literature: Quality; Quantity; and Price (Lo Nigro and Abbate, 2011). While the formal and informal governance types are mutually exclusive, and structure options are also mutually exclusive, 
orientation options are not. For example, organizations may have arrangements that specify one, two, or all three of the orientation specifications. Additionally, the three IOR types are not mutually exclusive from each other. For example, orientation IOR tends to be formal in their governance as are those involving FBO. Buyers seeking to reduce their engagement cost with farmers may want to deal with a group of farmers organized into a FBO instead of individual farmers (Adaku and Amanor-Boadu, 2021; Poole and De Frece, 2010; Salifu et al., 2012). Also, direct-to-buyer relationships could employ different orientation definitions, such as quality and price orientation. In general, orientation relationships are formal in governance, and the likelihood of formal governance increases when more than one supplier (farmer) is involved.

Comparing performance outcomes for participants across the different relationships with those operating on the spot market shows that participating in relationships produces superior performance outcomes for farmers (Abdul-Rahaman and Abdulai, 2019; Dubbert, 2019; Miyata et al., 2009). What is missing in the literature is the link between the type of relationship and the performance outcome. This research contributes to addressing this gap.

\section{Data and methods}

The data for the research was collected from farmers in Ghana using a structured questionnaire in August 2019. The questionnaire was piloted with a dozen farmers to ascertain validity and reliability. A total of 345 farmers were interviewed using the snowball sampling technique. The snowball began with an initial list of 110 farmers provided by two agro-processors. Ninety of these farmers were interviewed and asked to provide the name and contact information of other farmers they knew. The list they provided was checked, duplicates removed, and the remaining list interviewed, with each interview ending with a request for contacts.

The questions were organized into farmers' participation status and characteristics, enterprise profile, production options, and demographics. Enterprise profile focused on crops produced strictly for sale, and not for household consumption, and their allocated land. They encompassed 37 crops commonly produced in Ghana (MoFA, 2016), which were organized into five categories: Fruits; grains, legumes and oilseeds, root crops, and tree nuts.

To establish participation status, farmers were asked to state whether they were involved in any form of relationship with any of their buyers. Those responding in the affirmative were asked about the nature of their relationship by the type of governance, structure, and orientation. For example, for governance, they were asked to indicate whether their relationship had written agreements about expectations, and for orientation, they were asked to indicate if they had agreements about price, quality, and/or quantity prior to production. For structure, they were asked to indicate the approach they used to form the relationship, choosing among direct-to-buyer, FBO, or agent or broker. The questionnaire also solicited farmers' socioeconomic characteristics - age, gender, farming experience, controlled farmland, formal education, and off-farm and farm income for the previous production season. Also, information on the farmer's full-time farming status was solicited.

The literature had suggested that the benefits from participation in IOR are influenced by the participants' enterprise (Saxton, 1997), the type of relationship (Oliver, 1990; Williamson, 1985), and participants' demographic characteristics (Hofstede et al., 2010). Based on this, the marginal benefit experienced by farmers participating in IOR was regressed on their enterprise, demographic characteristics, and IOR type using an OLS regression model. The estimated parameters provide the marginal effect for the explanatory variables on the marginal benefit from the IOR. The empirical specification of the model is given as:

$$
\begin{aligned}
M B= & \alpha+\beta_{1} \text { Crop }+\beta_{2} \text { Fminc }+\beta_{3} \text { Offinc }+\beta_{4} \text { Age }+\beta_{5} E d u c+\beta_{6} \text { Occ }+\beta_{7} \text { Gen }+ \\
& \beta_{8} F m x+\gamma G+\sum_{s=1}^{3} \lambda_{s} S_{s}+\sum_{r=1}^{3} \sigma_{r} T+\varepsilon
\end{aligned}
$$


where $\varepsilon$ is the regression error term, $\mathrm{G}$ is governance, $\mathrm{S}$ is structure, and $\mathrm{T}$ is orientation. The components of structure and orientation are organized into categorical variables, and they, along with the questions used to solicit them from farmers, and the a priori expectations for their coefficients, are defined in Table 1. The regression coefficients were estimated using STATA/IC 14.2 (StataCorp LLC, College Station, TX, USA).

Table 1. Explanatory variables hypothesized to influence farmers' marginal net benefit.

\begin{tabular}{|c|c|c|c|}
\hline Variable & Measurement unit & Questionnaire & $\begin{array}{l}\text { A priori } \\
\text { expectation }\end{array}$ \\
\hline $\begin{array}{l}\text { Age } \\
(\text { Age })\end{array}$ & Years & How old are you? & $+/-$ \\
\hline $\begin{array}{l}\text { Education } \\
(E d u c)\end{array}$ & Years & $\begin{array}{l}\text { Please tell us the number of years of formal education } \\
\text { you have received. }\end{array}$ & + \\
\hline $\begin{array}{l}\text { Gender } \\
(\text { Gen })\end{array}$ & $\begin{array}{l}\text { Male }=1 \\
\text { Female }=0\end{array}$ & Are you male or female? & $+/-$ \\
\hline $\begin{array}{l}\text { Farm income } \\
\text { (Fminc) }\end{array}$ & Ghana Cedis (GHS) & $\begin{array}{l}\text { To the best of your ability, could you please provide } \\
\text { us with your best estimate of your total monthly farm } \\
\text { income for the last year. }\end{array}$ & $+/-$ \\
\hline $\begin{array}{l}\text { Off-farm income } \\
(\text { Offinc })\end{array}$ & Ghana Cedis (GHS) & $\begin{array}{l}\text { To the best of your ability, could you please provide } \\
\text { us with your best estimate of your total monthly off- } \\
\text { farm income for the last year? }\end{array}$ & $+/-$ \\
\hline $\begin{array}{l}\text { Occupation } \\
(O c c)\end{array}$ & $\begin{array}{l}\text { Full-time }=1 \\
\text { Part time }=0\end{array}$ & Are you a full-time farmer? & + \\
\hline $\begin{array}{l}\text { Farming experience } \\
(F m x)\end{array}$ & Years & $\begin{array}{l}\text { How many years of experience have you had as a } \\
\text { farmer? }\end{array}$ & + \\
\hline Crop enterprise & $\begin{array}{l}\text { Fruit } \text { crop }=1 \\
\text { Other } \text { crop }=0\end{array}$ & $\begin{array}{l}\text { Which of the following crops do you currently } \\
\text { produce with the primary purpose of selling them? }\end{array}$ & $+/-$ \\
\hline $\begin{array}{l}\text { Relationship types } \\
\text { under structure } \\
(S)\end{array}$ & $\begin{array}{c}\mathrm{S}=1: \text { Direct-to-buyer } \\
\quad(\text { Yes }=1, \mathrm{No}=0) \\
\mathrm{S}=2: \text { FBOs } \\
\quad(\mathrm{Yes}=1, \mathrm{No}=0) ; \\
\mathrm{S}=3: \text { Agent } \\
\quad(\text { Yes }=1, \mathrm{No}=0)\end{array}$ & $\begin{array}{l}\text { Farmers may enter into formal relationships with } \\
\text { buyers through multiple means. They may develop } \\
\text { direct relationships with their buyers, develop their } \\
\text { relationships through their farmer-based associations, } \\
\text { or they may develop their relationships through an } \\
\text { agent (an individual or a company that acts on behalf } \\
\text { of the farmer). Please indicate which method you used } \\
\text { to develop your relationship with buyers }\end{array}$ & $+/-$ \\
\hline $\begin{array}{l}\text { Relationship types } \\
\text { under orientation } \\
(T)\end{array}$ & $\begin{array}{c}\mathrm{T}=1: \text { Quantity } \\
\quad(\text { Yes }=1, \mathrm{No}=0) \\
\mathrm{T}=2: \text { Quality } \\
\quad(\text { Yes }=1, \mathrm{No}=0) \\
\mathrm{T}=3: \text { Price } \\
\quad(\text { Yes }=1, \mathrm{No}=0)\end{array}$ & $\begin{array}{l}\text { Partner arrangements may be focused on quantity, } \\
\text { quality, price, or their combinations. Please indicate } \\
\text { which of the following focus areas apply to each of } \\
\text { the formal relationships you have with buyers }\end{array}$ & $+/-$ \\
\hline $\begin{array}{l}\text { Relationship types } \\
\text { under governance } \\
(G)\end{array}$ & $\begin{array}{l}\text { Formal agreement }=1 \\
\text { Informal agreement }=0\end{array}$ & $\begin{array}{l}\text { Governance is about accountability. Organizations } \\
\text { use various governance mechanisms to manage their } \\
\text { relationships. Please select the mechanisms being } \\
\text { used to manage your current relationships with } \\
\text { buyers. }\end{array}$ & + \\
\hline
\end{tabular}




\section{Results and discussion}

The relevant summary statistics for IOR participants and non-participants are presented in Table 2. It shows that $151(43.8 \%)$ of the 345 respondents with the relevant data for analysis were IOR participants with an average farm income of GHS 3,947, which was more than 3.1 times that of non-participants and it is statistically different $(P=0.0846)$. Indeed, the two groups differed statistically across all variables except gender. For example, the average age and farming experience of participants were 49.46 years and 20.78 years, about 3 years and 2 years higher than those of non-participants. The differences were both statistically significant, with $P=0.0088$ and 0.0841 , respectively. Similarly, participants tend to operate larger farms, averaging about 40.85 acres compared to 13.40 for non-participants. As a result of their participation, they get the opportunity to earn premiums that offer them a benefit. The average participant marginal benefit was $16.34 \%$ with a standard deviation of $28.34 \%$, which was statistically different from zero $(P=0.000)$. The conclusion from Table 2 is that an IOR participant is likely to be older and more experienced, with a larger farm and higher farm income.

\subsection{Types of inter-organizational relationships used by farmers in Ghana}

The results showed that direct-to-buyer IOR was the dominant relationship under structure types, accounting for $71.50 \%$ of the farmers who participate in relationships. Farmer-based organizations accounted for $25.17 \%$ and agent IOR was the least popular, accounting for only $5.30 \%$ of respondents. That the sum of these proportions may exceed $100 \%$ is because some farmers selected multiple relationships under the structure types. For example, $1.3 \%$ of the farmers used both direct-to-buyer IOR and farmer-based organizations. Additionally, $0.7 \%$ of farmers used both farmer-based organizations and Agents. Table 3 presents the

Table 2. Summary socioeconomic statistics. ${ }^{1}$

\begin{tabular}{|c|c|c|c|c|}
\hline Variable & Mean & Std. Dev. ${ }^{2}$ & Minimum & Maximum \\
\hline \multicolumn{5}{|c|}{ Participant $=0(\mathrm{No})(\mathrm{n}=194)$} \\
\hline Farm income & $1,259.24(\$ 242.16)$ & $1,736.16$ & $33.00(\$ 6.35)$ & $17,500.00(\$ 3,365.38)$ \\
\hline Off-farm income & $2,057.23(\$ 395.62)$ & $2,618.87$ & $250.00(\$ 48.08)$ & $25,000.00(\$ 4,807.69)$ \\
\hline Farming experience & 18.70 & 11.38 & 2.00 & 50.00 \\
\hline Education & 8.81 & 4.61 & 0.00 & 20.00 \\
\hline Age & 46.09 & 11.76 & 20.00 & 81.00 \\
\hline Gender & 0.78 & & 0.00 & 1.00 \\
\hline Acreage & 13.40 & 11.61 & 1.00 & 63.00 \\
\hline Fruits & 0.07 & & 0.00 & 1.00 \\
\hline Occupation & 0.50 & & 0.00 & 1.00 \\
\hline \multicolumn{5}{|c|}{ Participant $=1$ (Yes) $(\mathrm{n}=151)$} \\
\hline Farm income & $3,946.89(\$ 759.02)$ & $21,580.74$ & $39.00(\$ 7.50)$ & $260,156.00(\$ 50,030.00)$ \\
\hline Off-farm income & $2,362.79(\$ 454.38)$ & $3,059.75$ & $10.00(\$ 1.92)$ & $17,350.00(\$ 3,336.54)$ \\
\hline Farming experience & 20.78 & 10.54 & 2.00 & 50.00 \\
\hline Education & 10.18 & 4.55 & 0.00 & 20.00 \\
\hline Age & 49.46 & 12.03 & 19.00 & 83.00 \\
\hline Gender & 0.77 & & 0.00 & 1.00 \\
\hline Acreage & 40.85 & 143.14 & 1.00 & $1,700.00$ \\
\hline Fruits & 0.25 & & 0.00 & 1.00 \\
\hline Occupation & 0.59 & & 0.00 & 1.00 \\
\hline Marginal benefit (\%) & 16.34 & 28.34 & 0 & 100 \\
\hline
\end{tabular}


Table 3. Farmers' characteristics and relationship structure used by participating farmers. ${ }^{1}$

\begin{tabular}{|c|c|c|c|c|c|c|}
\hline \multirow[t]{2}{*}{ Variables } & \multicolumn{2}{|c|}{ Direct-to-buyer $(n=108)$} & \multicolumn{2}{|c|}{ FBO $(n=38)$} & \multicolumn{2}{|c|}{ Agent $(\mathrm{n}=8)$} \\
\hline & Mean & Std. Dev. ${ }^{2}$ & Mean & Std. Dev. & Mean & Std. Dev. \\
\hline Farm income & $\begin{array}{l}5,113.10 \\
(\$ 983.29)\end{array}$ & $25,448.46$ & $\begin{array}{l}927.29 \\
(\$ 178.33)\end{array}$ & 927.12 & $\begin{array}{l}1,976.50 \\
(\$ 380.10)\end{array}$ & $1,531.99$ \\
\hline Off-farm income & $\begin{array}{l}2,725.50 \\
(\$ 524.13)\end{array}$ & $3,404.56$ & $\begin{array}{l}1,315.76 \\
(\$ 253.03)\end{array}$ & $1,233.10$ & $\begin{array}{l}2,714.00 \\
(\$ 521.92)\end{array}$ & $1,746.92$ \\
\hline Farming experience & 19.92 & 10.91 & 22.76 & 9.27 & 24.00 & 12.71 \\
\hline Education & 10.57 & 4.43 & 9.00 & 4.27 & 10.25 & 5.42 \\
\hline Age & 48.39 & 12.00 & 52.05 & 11.23 & 52.00 & 10.31 \\
\hline Gender & 0.83 & & 0.61 & & 0.75 & \\
\hline Acreage & 50.69 & 171.31 & 16.11 & 22.39 & 16.13 & 9.78 \\
\hline Fruits & 0.24 & & 0.29 & & 0.25 & \\
\hline Occupation & 0.62 & & 0.50 & & 0.50 & \\
\hline Marginal benefit & 16.05 & 28.85 & 16.35 & 25.59 & 16.25 & 30.68 \\
\hline
\end{tabular}

summary statistics of the structure-based IOR by farmer characteristics. Using the Wilks' lambda test for equality of means across all groups, assuming homogeneity, showed that the farmer characteristics that were statistically different were off-farm income $(P=0.0702)$ and gender $(P=0.0627)$. The average farm income under direct-to-buyer relationships was GHS 5,113, compared to less than GHS 1000 for the FBO and nearly GHS 2,000 for the Agents. Similarly, the average farm size under direct-to-buyer relationships was about 50 acres, compared to about 16 acres for FBOs and Agents. Finally, while males accounted for approximately $83 \%$ of those using direct-to-buyer relationships, they accounted for about six in 10 and three-quarters of those using FBO and Agent relationships, respectively. The average marginal benefit was about $16 \%$ for all three IOR structures. The foregoing suggests that farmers using direct-to-buyer relationships tend to be male, relatively young, and more educated. They also are predominantly full-time farmers with larger farms and have higher farm incomes.

Figure 1 shows the distribution of IOR farmers by the orientation of the relationship. It shows that most farmers $(81 \%)$ had quality, $54 \%$ had price and about $29 \%$ had quantity specified in their orientation-based relationships with buyers. Approximately $22 \%$ of them had all three orientations specified in their relationship and $36 \%$ had only quality specified.

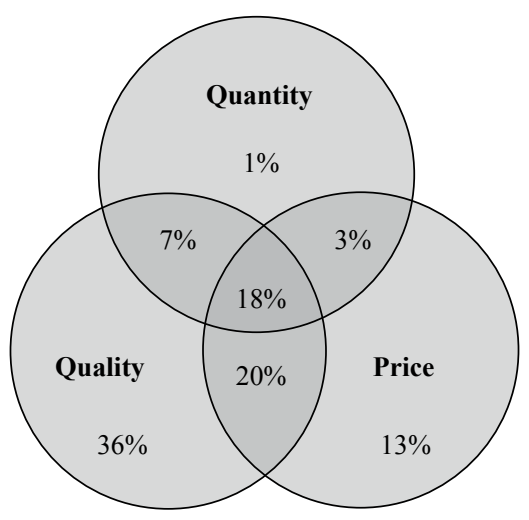

Figure 1. Orientation of farmers' relationships $(\mathrm{n}=151)$. 
Although Table 4a and Table 4b present the summary statistics of the seven orientation-based IOR by farmer characteristics, the number of participants in the quantity-only orientation and the price-quantity orientation technically offers only five groups of credible interest. Farmers in price-quality-quantity orientation relationships have the highest average farm and off-farm incomes and the highest average acreage. About nine in 10 of the farmers in this category are male, which was about the same as for quantity-quality orientation relationship. The average marginal benefit for the price-quality relationship was estimated at

Table 4a. Summary statistics for orientation-based relationships by farmer characteristics. ${ }^{1}$

\begin{tabular}{|c|c|c|c|c|c|c|}
\hline \multirow[t]{2}{*}{ Variable } & \multicolumn{2}{|c|}{ Price $(n=20)$} & \multicolumn{2}{|c|}{ Quantity $(n=2)$} & \multicolumn{2}{|c|}{ Quality $(n=57)$} \\
\hline & Mean & Std. Dev. ${ }^{2}$ & Mean & Std. Dev. & Mean & Std. Dev. \\
\hline Farm income & $\begin{array}{l}843.95 \\
(\$ 162.30)\end{array}$ & 619.66 & $\begin{array}{l}360.00 \\
(\$ 69.23)\end{array}$ & 0.00 & $\begin{array}{l}788.18 \\
(\$ 151.57)\end{array}$ & 677.00 \\
\hline Off-farm income & $\begin{array}{l}1,409.45 \\
(\$ 271.05)\end{array}$ & 904.25 & $\begin{array}{l}470.00 \\
(\$ 90.38)\end{array}$ & 28.28 & $\begin{array}{l}1,158.61 \\
(\$ 222.81)\end{array}$ & $1,019.63$ \\
\hline Farming experience & 16.68 & 9.75 & 18.50 & 16.26 & 21.96 & 10.38 \\
\hline Education & 10.35 & 2.94 & 6.00 & 0.00 & 8.88 & 3.53 \\
\hline Age & 44.15 & 11.75 & 43.00 & 18.38 & 50.40 & 10.26 \\
\hline Gender & 0.81 & & 0.50 & & 0.68 & \\
\hline Acreage & 10.00 & 6.59 & 9.00 & 1.41 & 12.37 & 16.80 \\
\hline Fruits & 0.00 & & 0.00 & & 0.07 & \\
\hline Occupation & 0.60 & & 1.00 & & 0.58 & \\
\hline Marginal benefit & 6.05 & 10.73 & 0.00 & 0.00 & 6.67 & 4.84 \\
\hline
\end{tabular}

${ }^{1}$ US Dollar equivalent in parenthesis is based on the World Bank average 2019 exchange rate at $\$ 1=$ GHS5.2 as data was collected in 2019 (https://data.worldbank.org/indicator/PA.NUS.FCRF?locations=GH).

${ }^{2}$ Std. Dev. $=$ standard deviation.

Table 4b. Summary statistics for orientation-based relationships by farmer characteristics. ${ }^{1}$

\begin{tabular}{|c|c|c|c|c|c|c|c|c|}
\hline \multirow[t]{2}{*}{ Variable } & \multicolumn{2}{|c|}{$\begin{array}{l}\text { Price-quality-quantity } \\
(n=27)\end{array}$} & \multicolumn{2}{|c|}{$\begin{array}{l}\text { Price-quantity } \\
(n=5)\end{array}$} & \multicolumn{2}{|c|}{$\begin{array}{l}\text { Price-quality } \\
(n=30)\end{array}$} & \multicolumn{2}{|c|}{$\begin{array}{l}\text { Quality-quantity } \\
(n=10)\end{array}$} \\
\hline & Mean & Std. Dev. ${ }^{2}$ & Mean & Std. Dev. & Mean & Std. Dev. & Mean & Std. Dev. \\
\hline Farm income & $\begin{array}{l}15,840.44 \\
(\$ 3,046.24)\end{array}$ & $43,478.07$ & $\begin{array}{l}401.80 \\
(\$ 77.27)\end{array}$ & 229.36 & $\begin{array}{l}2,894.43 \\
(\$ 556.62)\end{array}$ & $7,738.17$ & $\begin{array}{l}1,692.20 \\
(\$ 325.42)\end{array}$ & $1,084.24$ \\
\hline Off-farm income & $\begin{array}{l}5,986.04 \\
(\$ 1,151.16)\end{array}$ & $4,732.16$ & $\begin{array}{l}759.80 \\
(\$ 146.12)\end{array}$ & 425.84 & $\begin{array}{l}2,475.60 \\
(\$ 476.08)\end{array}$ & $2,315.47$ & $\begin{array}{l}2,192.20 \\
(\$ 421.58)\end{array}$ & $1,027.14$ \\
\hline Farming experience & 17.93 & 10.78 & 18.40 & 8.73 & 24.80 & 11.95 & 19.30 & 7.47 \\
\hline Education & 12.70 & 4.32 & 6.40 & 8.91 & 11.17 & 5.77 & 10.20 & 1.03 \\
\hline Age & 47.33 & 13.37 & 41.80 & 15.19 & 54.43 & 12.10 & 50.70 & 10.18 \\
\hline Gender & 0.93 & & 0.80 & & 0.77 & & 0.90 & \\
\hline Acreage & 140.96 & 290.63 & 9.00 & 7.25 & 38.27 & 58.05 & 24.70 & 17.54 \\
\hline Fruits & 0.48 & & 0.40 & & 0.47 & & 0.40 & \\
\hline Occupation & 0.48 & & 0.40 & & 0.73 & & 0.50 & \\
\hline Marginal benefit & 13.08 & 24.35 & 17.00 & 22.25 & 49.78 & 44.26 & 3.30 & 4.72 \\
\hline
\end{tabular}

${ }^{1}$ US Dollar equivalent in parenthesis is based on the World Bank average 2019 exchange rate at $\$ 1=$ GHS5.2 as data was collected in 2019 (https://data.worldbank.org/indicator/PA.NUS.FCRF?locations=GH).

${ }^{2}$ Std. Dev. $=$ standard deviation. 
$49.78 \%$, compared to about $17 \%$ for both price-quality-quantity and the price-quantity relationships. All other relationships post single-digit marginal benefit. Using the Wilks' lambda test for equality of means across all the seven groups, assuming homogeneity, showed that the farmer characteristics that were statistically different were the following: off-farm income $(P=0.000)$; education $(P=0.011)$; age $(P=0.073)$; acreage $(P=0.038)$; and fruits $(P=0.000)$. The marginal benefits were also statistically different across the seven orientation-based IOR $(P=0.000)$.

The final IOR group is governance, and it was dichotomized into formal and informal types. The results indicated that $68.9 \%$ of the 151 IOR participants used informal agreements compared to $31.1 \%$ using formal agreements. Table 5 presents summary statistics for the governance-based relationships by farmer characteristics. The results show that acreage, education, and off-farm income under formal agreements were statistically different from those under informal agreements with $P=0.032, P=0.0000$, and $P=0.0206$, respectively. The difference between the proportions of males and fruit growers under formal and informal agreements were both statistically significant with $P=0.0321$ and $P=0.0000$, respectively. Likewise, the difference in the proportion of full-time farmers under formal and informal agreements was statistically significant $(P=0.0284)$. It might, therefore, be concluded from the foregoing that farmers participating in IOR using formal agreements tend to be more educated males with larger operations, growing fruits, and have higher incomes compared to those using informal agreements.

Table 5. Summary statistics of governance-based relationships by farmer characteristics. ${ }^{1}$

\begin{tabular}{|c|c|c|c|c|}
\hline \multirow[t]{2}{*}{ Farmers' characteristics } & \multicolumn{2}{|c|}{ Formal agreement $(n=47)$} & \multicolumn{2}{|c|}{ Informal agreement $(n=104)$} \\
\hline & Mean & Std. Dev. $^{2}$ & Mean & Std. Dev. \\
\hline Farm income & $9,411.72(\$ 1,809.95)$ & $38,154.41$ & $1,477.21(\$ 284.08)$ & $2,883.45$ \\
\hline Off-farm income & $3,433.83(\$ 660.35)$ & $3,710.90$ & $1,878.77(\$ 361.0)$ & $2,521.63$ \\
\hline Farm experience & 20.43 & 9.94 & 20.94 & 11.08 \\
\hline Education & 12.45 & 4.88 & 9.15 & 3.94 \\
\hline Age & 49.81 & 12.57 & 49.31 & 11.59 \\
\hline Gender & 0.89 & & 0.72 & \\
\hline Acreage & 96.57 & 255.60 & 15.67 & 18.87 \\
\hline Fruits & 0.47 & & 0.14 & \\
\hline Occupation & 0.70 & & 0.54 & \\
\hline Marginal benefit & 31.51 & 38.91 & 9.47 & 18.01 \\
\hline
\end{tabular}

${ }^{1}$ US Dollar equivalent in parenthesis is based on the World Bank average 2019 exchange rate at $\$ 1=$ GHS5.2 as data was collected in 2019 (https://data.worldbank.org/indicator/PA.NUS.FCRF?locations=GH).

2 Std. Dev. = standard deviation. 


\subsection{Type and marginal benefit}

This section presents the results of the OLS regression estimating the relationship between marginal benefit and IOR types while controlling for farmers' socioeconomic characteristics (Equation 6). The model statistics indicate an R-squared of $45.85 \%$ with an $\mathrm{F}(19,131)$ of $5.84(P=0.000)$.

The results are presented in Table 6, and they show that the only farmer characteristic with a statistically significant impact on marginal benefit is off-farm income. Holding all other variables constant, the marginal effect of off-farm income (a GHS 1/month increase) on marginal benefit was $-0.002 \%(P=0.061)$. Among the IOR, formal governance, and quality-price orientation relationship were the only ones with statistically significant marginal effects on the marginal benefit. Having a formal agreement instead of an informal agreement with buyers increases marginal benefit by $10.26 \%(P=0.040)$ and having a quality-price orientation relationship producers a marginal benefit impact of almost $28.90 \%(P=0.000)$, ceteris paribus. The hypotheses about their a priori expectations are, thus, rejected. All other IOR arrangements did not have a statistically significant marginal effect on marginal benefit. Therefore, the a priori expectations about their impact on marginal benefit cannot be rejected. Likewise, while both occupation and farming experience had the expected signs on their coefficients, the hypothesis about their a priori expectations cannot be rejected because the coefficients are not statistically significant.

These findings are also consistent with Dubbert (2019) who found that characteristics such as age, education, gender and farm size farmers in IOR did not have a significant marginal effect on their price margins. They also found that farmers engaged in IOR who use farmer-based organisations did not have a significant effect on price margins. The results from this paper fall in this line indicating that it would not matter for farmers to develop their IOR directly with buyers, through farmer-based organizations or agents. Some studies have

Table 6. Regression results of marginal benefits from alternative inter-organizational relationships and participants' characteristics $(\mathrm{n}=151){ }^{1}$

\begin{tabular}{lcccc}
\hline Variable & Coefficient & Std. Err. & t & P>t \\
\hline Fruits = Yes & 3.407 & 5.168 & 0.660 & 0.511 \\
Farm income & 0.000 & 0.000 & 0.400 & 0.693 \\
Off-farm income & $-0.002^{*}$ & 0.001 & -1.890 & 0.061 \\
Age & -0.005 & 0.228 & -0.020 & 0.983 \\
Education & 0.520 & 0.478 & 1.090 & 0.278 \\
Farming experience & 0.038 & 0.240 & 0.160 & 0.873 \\
Acreage & -0.005 & 0.014 & -0.330 & 0.739 \\
Occupation = Full-time & 6.829 & 4.425 & 1.540 & 0.125 \\
Gender = Male & 1.761 & 4.826 & 0.360 & 0.716 \\
Governance = Formal & $10.258^{* *}$ & 4.957 & 2.070 & 0.040 \\
Direct-to-buyer = Yes & -5.176 & 14.792 & -0.350 & 0.727 \\
FBO = Yes & 1.063 & 14.406 & 0.070 & 0.941 \\
Agent = Yes & 5.672 & 16.146 & 0.350 & 0.726 \\
Quantity\#Quality\#Price & & & & \\
$\quad$ No\#No\#Yes & -9.460 & 8.025 & -1.180 & 0.241 \\
No\#Yes\#No & -8.753 & 7.399 & -1.180 & 0.239 \\
$\quad$ No\#Yes\#Yes & $28.897 * * *$ & 6.707 & 4.310 & 0.000 \\
Yes\#No\#No & -13.323 & 17.400 & -0.770 & 0.445 \\
Yes\#No\#Yes & -1.850 & 12.491 & -0.150 & 0.882 \\
Yes\#Yes\#No & -15.310 & 9.616 & -1.590 & 0.114 \\
Intercept & 7.912 & 19.484 & 0.410 & 0.685 \\
\hline 1***** and * represent the 1,5 and 10\% significance levels, respectively. FBO & farmer-based organization; Std. Err. = standard error.
\end{tabular}


shown the benefits of farmer-based organizations to farmers (Salifu et al., 2012) however, the result from this paper provides insights when promoting farmer-based organizations for farmers who participate in IOR. Abdul-Rahaman and Abdulai (2019) also found that farmers who use either verbal (informal) or written (formal) contracts perform better than farmers who sell in the spot markets. This paper provides further insight that farmers who use formal relationships have a relatively higher marginal benefit compared with farmers who use informal relationships.

The results provide a clear focus on IOR that have the potential to enhance farmers' economic wellbeing. Given that no demographic characteristic of farmers affected the marginal benefit of participating in IOR, it means that all farmers have the potential to benefit from participation. Theoretically, there should be no barriers to effective performance in IOR imposed by the socio-demographic characteristics of farmers, and this research confirms that. Constructing the regression model to reflect all the IOR options available revealed that to enhance the marginal benefits created by participation, only one IOR produces a statistically significant positive effect, i.e. quality-price orientation IOR.

\section{Conclusions}

The paper was premised on the potential value from IOR. It sought to address the gaps in the literature regarding dominant relationships in Ghana's agricultural production community, and the relative marginal benefit emanating from these IOR. The paper classified three broad IOR: Governance; Structure; and Orientation. It found that about $31 \%$ of the farmers participating in IOR used formal governance. The majority (about $72 \%$ ) of farmers participating in IOR used direct-to-buyer relationships and approximately $25 \%$ used FBO to facilitate their IOR. Only 5\% of IOR participating farmers used agents or brokers. Accounting for more than eight in ten IOR, relationships involving quality orientation were the dominant IOR.

While the statistical analysis showed that demographic and socio-economic characteristics influenced the choice of IOR, the regression analysis showed that they had no impact on performance. In other words, no particular demographic and socio-economic group has a distinguished advantage over others in doing well with IOR. The results show that no one of the structural arrangements - direct-to-buyer, FBO, and agents - have any statistically significant advantage in producing superior marginal benefit. Hence, any of them may be employed given specific circumstances that warrant them without prejudice. The same is not true for governance and orientation-based IOR. The results indicated that formal governance relationships produced statistically significant marginal benefits vis-à-vis informal governance relationships. Also, while most of the orientation-based IOR types showed no statistically significant effect on marginal benefits associated with IOR participation, the quality-price orientation IOR exhibited statistically significant positive impacts. These results provide clear direction for policymakers and practitioners to direct farmers' participation in the IOR that produce superior economic outcomes. That Ghanaian farmers are similar in their production practices, IOR options, and socio-economic and demographic characteristics would enable the application of these results to other locations in the selection and implementation of high performing IOR.

\section{Financial support}

The work was sponsored by the BHEARD program operated by the United States Agency for International Development, as part of the Feed the Future initiative, and was managed under the CGIAR Fund, Award Number BFS-G-11-00002, and the predecessor fund the Food Security and Crisis Mitigation II grant, Award Number EEM-G-00-04-00013. The funding is gratefully acknowledged. 


\section{References}

Abdul-Rahaman, A. and A. Abdulai. 2019. Vertical coordination mechanisms and farm performance amongst smallholder rice farmers in Northern Ghana. Agribusiness 36(2): 259-280. https://doi.org/10.1002/ agr. 21628

Adaku, A.A. and V. Amanor-Boadu. in press. Transaction costs and inter-organizational relations between farmers and farm product buyers in Ghana. Journal of Agribusiness in Developing and Emerging Economies. https://doi.org/10.1108/JADEE-01-2021-0007

Alemu, A.E., M. Maertens, J. Deckers, H. Bauer and E. Mathijs. 2016. Impact of supply chain coordination on honey farmers' income in Tigray, Northern Ethiopia. Agricultural and Food Economics. https:// doi.org/10.1186/s40100-016-0053-X

Amanor-Boadu, V., P. Marletta and A. Biere. 2009. Entrepreneurial supply chains and strategic collaboration: the case of Bagòss Cheese in Bagolino, Italy. International Food and Agribusiness Management Review 12(3): 20.

Argyres, N.S. and T.R. Zenger. 2012. Capabilities, transaction costs, and firm boundaries. Organization Science 23(6): 1643-1657.

Barrett, C.B. 2008. Smallholder market participation: concepts and evidence from Eastern and Southern Africa. Food Policy 33(4): 299-317. https://doi.org/10.1016/j.foodpol.2007.10.005

Camanzi, L., E. Arba, C. Rota, C. Zanasi and G. Malorgio. 2018. A structural equation modeling analysis of relational governance and economic performance in agri-food supply chains: evidence from the dairy sheep industry in Sardinia (Italy). Agricultural and Food Economics 6(1): 1-22. https://doi. org/10.1186/s40100-018-0099-z

Castrogiovanni, G.J. 1991. Environmental munificence: a theoretical assessment. The Academy of Management Review 16(3): 542. https://doi.org/10.2307/258917

Choe, J.M. 2008. Inter-organizational relationships and the flow of information through value chains. Information and Management 45(7): 444-450. https://doi.org/10.1016/j.im.2008.06.006

Coase, RH. 1937. The nature of the firm. Economica 4(16): 386-405. https://doi.org/10.2307/2626876

Dubbert, C. 2019. Participation in contract farming and farm performance: insights from cashew farmers in Ghana. Agricultural Economics 50(6): 749-763. https://doi.org/10.1111/agec.12522

Frank, S.D. and D.R. Henderson. 1992. Transaction costs as determinants of vertical coordination in the U.S. food industries. American Journal of Agricultural Economics 74(4): 941-950. https://doi. org/10.2307/1243192

Galizzi, G. and L. Venturini. 1999. Vertical relationships and coordination in the food system. Springer, New York, NY, USA.

Ghanaian Ministry of Food and Agriculture (MoFA). 2016. Agriculture in Ghana: facts and figures, 2015. MoFA, Accra, Ghana.

Ghanaian Ministry of Food and Agriculture (MoFA). 2017. Planting for food and jobs. MoFA, Accra, Ghana.

Gomes-Casseres, B. 2003. Competitive advantage in alliance constellations. Strategic Organization 1(3): 327-335.

Henchion, M. and B. McIntyre. 2010. From transactions to relationships: the case of the Irish beef chain. In: C. Fisher and M. Hartmann (eds.) Agri-food chain relationships. CABI Publishing, Wallingford, UK. https://doi.org/10.1079/9781845936426.0150

Hobbs, J.E. 1995. A transaction cost analysis of finished beef marketing in the United Kingdom. PhD-thesis, University of Aberdeen, Aberdeen, UK. Available at: https://ethos.bl.uk/OrderDetails.do?uin=uk. bl.ethos.295221

Hobbs, J.E. 1997. Measuring the importance of transaction costs in cattle marketing. American Journal of Agricultural Economics 79(4): 1083-1095.

Hofstede, G.J., M. Fritz, M. Canavari, E. Oosterkamp and G.-J. Van Sprundel. 2010. Towards a cross-cultural typology of trust in B2B food trade. British Food Journal 112(6-7): 671-687.

Kataike, J. and X. Gellynck. 2018. 22 years of governance structures and performance: what has been achieved in agrifood chains and beyond? A review. Agriculture 8: 51. https://doi.org/10.3390/agriculture8040051 
Kitamura, H., M. Sato and K. Arai. 2014. Exclusive contracts when the incumbent can establish a direct retailer. Journal of Economics 112(1): 47-60.

Krathu, W., C. Pichler, G.H. Xiao, H. Werthner, J. Neidhardt, M. Zapletal and C. Huemer. 2015. Interorganizational success factors: a cause and effect model. Information Systems and e-Business Management 13(3): 553-593. https://doi.org/10.1007/s10257-014-0258-z

Lo Nigro, G. and L. Abbate. 2011. Risk assessment and profit sharing in business networks. International Journal of Production Economics 131(1): 234-241. https://doi.org/10.1016/j.ijpe.2009.08.014

Miyata, S., N. Minot and D. Hu. 2009. Impact of contract farming on income: linking small farmers, packers, and supermarkets in China. World Development 37(11): 1781-1790. https://doi.org/10.1016/j. worlddev.2008.08.025

Nigh, R. 1997. Organic agriculture and globalization. A Maya associative corporation in Chiapas, Mexico. Human Organization 56(4): 427-436.

Oliver, C. 1990. Determinants of interorganizational relationships: integration and future directions. Academy of Management Review 15(2): 241-266. https://doi.org/10.5465/AMR.1990.4308156

Oya, C. 2012. Contract farming in sub-Saharan Africa: a survey of approaches, debates and issues. Journal of Agrarian Change 12(1): 1-34. https://doi.org/10.1111/j.1471-0366.2011.00337.x

Poku, A.-G., R. Birner and S. Gupta. 2018. Making contract farming arrangements work in Africa's bioeconomy: evidence from cassava outgrower schemes in Ghana. Sustainability 10(5): 1604. https://doi.org/10.3390/su10051604

Poole, N. and A. De Frece. 2010. A review of existing organisational forms of smallholder farmers' associations and their contractual relationships with other market participants in the East and Southern African ACP Region. AAACP Paper Series - No. 11. Food and Agriculture Organisation, Rome, Italy.

Provan, K.G. and J. Sydow. 2009. Evaluating inter-organizational relationships. In: S. Cropper, C. Huxham, M. Ebers and S.P. Ring (eds.) The Oxford handbook of inter-organizational relations. Oxford University Press, Oxford, UK. https://doi.org/10.1093/oxfordhb/9780199282944.003.0026

Rao, E.J.O. and M. Qaim. 2011. Supermarkets, farm household income, and poverty: insights from Kenya. World Development 39(5): 784-796. https://doi.org/10.1016/j.worlddev.2010.09.005

Salifu, A., R.L. Funk, M. Keefe and S. Kolavalli. 2012. Farmer based organizations in Ghana. IFPRI Working Paper 31. IFPRI-Accra, Accra, Ghana. Available at: https://researchdirect.westernsydney. edu.au/islandora/object/uws:19138/datastream/PDF/view

Saxton, T. 1997. The effects of partner and relationship characteristics on alliance outcomes. The Academy of Management Journal 40(2): 443-461. https://doi.org/10.2307/256890

Simpson, C.R. and A. Rapone. 2000. Community development from the ground up: social-justice coffee. Human Ecology Review 7(1): 46-57.

Williamson, O.E. 1973. Markets and hierarchies, some elementary considerations. American Economic Review 63(2): 316-325.

Williamson, O.E. 1985. The economic institutions of capitalism: firms, markets, relational contracting. University of Illinois at Urbana-Champaign's Academy for Entrepreneurial Leadership Historical Research Reference in Entrepreneurship. Available at: https://ssrn.com/abstract=1496720

Yameogo, T.B., A.Y. Bossa, B.M. Torou, J.-L. Fusillier, D.E.C. Da, Y. Yira, G. Serpantie, F. Somé and M.M. Dama-Balima. 2018. Socio-economic factors influencing small-scale farmers' market participation: case of rice producers in Dano. Sustainability 10(12): 4354. https://doi.org/10.3390/su10124354 
